http://dx.doi.org/10.18778/0208-6050.95.05

BOGUSZ BOMANOWSKI

(UNIWERSYTET ŁÓDZKI)*

\title{
Współdziałanie wojsk Rzeczypospolitej Obojga Narodów w pierwszym etapie walk kampanii cudnowskiej
}

\section{Uwagi wstępne}

Na potrzeby analizy należy wyodrębnić dwie główne części kampanii: walki pod Lubarem i walki pod Cudnowem. W celu uporządkowania dalszego wywodu można wskazać sześć etapów walk kampanii cudnowskiej:

1. Pierwsze starcie, walki opóźniające.

2. Pierwsze szturmy taboru moskiewsko-kozackiego.

3. Marsz Lubar-Cudnów - walki z taborem w ruchu.

4. Cudnów - walki unieruchomionego taboru.

5. Słobodyszcze - atak sił pod dowództwem Jerzego Lubomirskiego na wojska Jerzego Chmielnickiego.

6. Cudnów - ostatnie walki i rozerwanie taboru moskiewsko-kozackiego.

Zaprezentuję tu kampanię w odniesieniu do ciągu walk łączącego się w całość. Dlatego też pomijam rozbicie obozu Werteleckiego przez dwa zgrupowania polskie: jedno kawaleryjskie i jedno kawaleryjsko-dragońskie. W artykule skupię się na analizie, w kontekście współdziałania, pierwszej części kampanii - jej trzech pierwszych etapów.

Ze względu na podjętą tematykę pojęcia „współdziałanie” oraz „formacje wojskowe" wymagają wyjaśnienia. Współdziałanie jest terminem opisującym złożone zjawisko, mające liczne odmiany. Jego cechą ogólną jest to, że muszą w nim występować przynajmniej dwa podmioty. Współdziałanie może oznaczać:

1. Działanie wspólnie z kimś.

2. Przyczynianie się do czegoś razem z innymi czynnikami.

3. Funkcjonowanie w powiązaniu $\mathrm{z}$ innymi ${ }^{1}$.

W języku potocznym współdziałanie to wspólna praca, pomaganie komuś w jakiejś działalności². To także właściwość każdego zorganizowanego działania

\footnotetext{
${ }^{*}$ Wydział Filozoficzno-Historyczny, Instytut Historii, Katedra Historii Nowożytnej.

${ }^{1}$ Stownik języka polskiego PWN, http://sjp.pwn.pl/slowniki/wsp\%C3\%B3\%C5\%82dzia\%C5\% 82anie.html (dostęp: 1 III 2016).
} 
ludzi. Atrybutem każdej organizacji jest określony poziom zdolności do współdziałania.

Celowo przyjmuję, że współdziałaniem jest połączenie działań, a nie ogół działań połączonych. To element koordynacji, świadomego powiązania jest w mojej ocenie najistotniejszy. Połączenie owo, choć świadome, niekoniecznie musi być zawsze w pełni planowe. Nieraz bywało wręcz wynikiem impulsu, improwizacji, posuniętych czasem tak dalece, że można by im postawić zarzut zbiegu okoliczności czy przypadku.

Podmiotami współdziałania są formacje wojskowe. Pojęcie to rozumiem szeroko. Mając na względzie ogrom zmian, w tym terminologicznych, zaistniałych od analizowanego przeze mnie okresu do czasów nam współczesnych, jak również to, że nie jest to praca adresowana wyłącznie do czynników wojskowych, nie będę się starał trzymać terminologicznych podziałów właściwych współczesnym naukom wojskowym (od dnia 8 sierpnia 2011 r. określanym jako nauki o obronności).

Formacje wojskowe to określenie najbardziej ogólne, które na potrzeby tej pracy może być stosowane w odniesieniu do zorganizowanych i dowodzonych, $\mathrm{w}$ pewnym stopniu jednolitych co do odgrywanej roli grup żołnierzy. Formacją wojskową będzie więc piechota typu niemieckiego, petyhorcy, lisowczycy czy husarze. Formacja jest zatem nie tyle pojęciem w swej stopniowalności mniejszym od broni (np. broń-kawaleria, formacja-rajtaria) ani też nie jedynie większym ilościowo od jednostek takich jak chorągwie czy regimenty. Odróżnia się samą substancją.

Bronie to inaczej rodzaje wojsk - $\mathrm{i}$ to ten ostatni termin, jako bardziej zrozumiały, będę stosował w dalszych rozważaniach. W omawianym okresie można wyodrębniać najwyżej sześć rodzajów wojsk: kawalerię, piechotę, traktowaną od nich odrębnie (w mojej ocenie słusznie) dragonię, a także artylerię, flotę, wojska inżynieryjne i pomocnicze. Kryteria tej klasyfikacji wymagają doprecyzowania ${ }^{3}$, choć wyodrębnione w jej zakresie kategorie raczej nie budzą istotnych wątpliwości $^{4}$. Dany rodzaj wojsk różnił się zatem od innych zespołem zintegrowanych

${ }^{2}$ B. K o ż u c h, O współdziałaniu. Dlaczego trzeba $i$ warto współdziałać, prezentacja ISP UJ: http://www.isp.uj.edu.pl/documents/2103800/58f23e0d-4f68-413f-b947-9f86f31691da (dostęp: 28 IX 2014).

${ }^{3}$ Najważniejsza praca, choć o 100 lat wcześniejsza, to kształtująca w omawianym okresie myślenie o strukturze armii: J.A. T a r n o w s k i, Consilium rationis bellicae, Tarnów 1558. Więcej na ten temat: B. B o m a n o w s k i, Sources of Development of the Indigenous Polish Military Doctrine in 16 $6^{\text {th }}$ Century: Comparison: Theory and Practice, [w:] Vēsture: avoti un cilvēki. Proceedings of the $25^{\text {th }}$ International Scientific Readings of the Faculty of Humanities. History XIX, red. I. Saleniece, Daugvapils 2016, s. 27-36.

${ }^{4}$ Nawet dragonia, mimo że pojawiła się w Rzeczypospolitej już po usystematyzowaniu struktury wojskowości przez J.A. Tarnowskiego, nie powodowała trudności klasyfikacyjnych, o czym świadczy konsekwentne operowanie tym pojęciem w większości relacji siedemnastowiecznych, co 
cech walczących żołnierzy lub zespołem zintegrowanych cech podstawowej jednostki bojowej.

Siły obydwu stron zarysowane będą z grubsza: nie jest celowe podawanie liczebności poszczególnych regimentów albo rot czy nazwisk ich dowódców zarówno ze względu na wiodący temat pracy, jak i na powszechną w staropolskiej sztuce wojennej (dalej określanej także jako SSzW) modułowość sił zbrojnych, objawiającą się zwłaszcza przez praktykę tworzenia sił zadaniowych, kombinowanych z pododdziałów czy luźnych, często ochotniczych lub wyborowych grup, wydzielonych ad hoc z różnych oddziałów etc.

Siły Rzeczypospolitej składały się z następujących komponentów:

1. Dywizja hetmana wielkiego koronnego Stanisława Potockiego, z typową dla struktury wojsk staropolskich wieku XVII przewagą jazdy nad piechotą.

2. Dywizja hetmana polnego koronnego Jerzego Lubomirskiego, cechująca się strukturą odmienną względem dywizji hetmana wielkiego, tj. z relatywnie liczną piechotą.

3. Orda tatarska, w sposób oczywisty zwiększająca ogólne siły lekkiej jazdy, pozostające w dyspozycji korpusu wojsk Rzeczypospolitej.

Dla zrównoważonego i elastycznego współdziałania bardzo ważną cechą jest to, że w szyku stosowanym przez hetmanów w kampanii cudnowskiej, zresztą nieobcym staropolskim taktykom, dość częste było ustawianie ogółu piechoty w centrum. Pozwalało to wyrównać (tu dość znaczne) dysproporcje w opatrzeniu piechotą każdej z dwu dywizji (wyraźnie, bo ponad dwukrotnie więcej piechoty u Lubomirskiego). Dzięki temu jeden z hetmanów mógł „pożyczać” piechurów od drugiego, a wspólna ich lokalizacja w środku szyku armii czyniła relatywnie krótką drogę, jaką regimenty piesze miały do pokonania. Pozwalało to współdziałać różnym oddziałom piechoty. Ponadto, jako mniej mobilna, była ona lo-

pozwala przyjąć, że autorzy tych tekstów za celowe uznawali traktowanie dragonii odrębnie od piechoty i jazdy.

${ }^{5}$ Zwrot przyjęty za R. S i k o r ą, Fenomen husarii, Warszawa 2013, s. 20, gdzie autor pisze o jednostce bojowej, mając na myśli husarza i jego konia bojowego traktowanych jako jeden, samodzielny, podstawowy element pola walki, słusznie zwracając uwagę na to, że husarz mógł funkcjonować w swej głównej roli taktycznej, o ile dysponował sprawnym wierzchowcem (w praktyce ze względu na znaczne straty - kilkoma wierzchowcami na zmianę). Przyjmując ten punkt widzenia, za ,jednostkę bojową" czy, jak wolę ją nazywać (aby uniknąć pomyłki z jednostką w znaczeniu np. chorągwi), „podstawową komórkę taktyczną” uznawać powinniśmy np. galerę z załogą i uzbrojeniem oraz całością osprzętu niezbędnego do manewrowania na wodzie. Tak też za podstawową komórkę taktyczną uznamy działo z kanonierami (ewentualnie można tu wliczać także zaprzęg, o ile da się wykazać taktyczną, a nie tylko logistyczną rolę przemieszczenia, swoiste manewrowanie artylerią na polu walki w toku wykonywania zadań taktycznych). Za zbędne należy uznać określenie podstawowej komórki taktycznej w przypadku piechoty - rolę tę odgrywa po prostu uzbrojony piechur. 
kowana w pozycji środkowej, stosunkowo najmniej sprzyjającej manewrom, stając się osią armii, wokół której obracały się manewry reszty wojsk. To z kolei sprzyjało współdziałaniu piechoty z jazdą. Ta ostatnia, bardziej mobilna, nie musiała być symetrycznie przydzielona obydwu dywizjom, gdyż wbrew opiniom części historyków zagranicznych manewry nieproporcjonalnymi skrzydłami, służące do „Zwichnięcia równowagi”, nie są w nowożytności datowane od czasów Fryderyka Wielkiego i nie stanowią jego odkrycia ${ }^{6}$. Dwa pokolenia przed Lubomirskim manewr nieproporcjonalnymi skrzydłami wykorzystywał doskonale Jan Karol Chodkiewicz pod Kircholmem.

Siły moskiewsko-kozackie pod wodzą Wasyla Szeremietiewa stanowiły połączenie dwóch modułów, z których każdy reprezentował cechy typowe dla danego typu wojskowości w omawianym okresie. Siły kozackie walczyły głównie pieszo, zarówno bronią palną, jak i białą. Znane są też przynajmniej dwa przypadki dość licznego wykorzystania przez nie łuków do rażenia ostrzałem stromotorowym ${ }^{7}$. Siły moskiewskie stanowiły połączenie piechoty typowej dla armii moskiewskiej, uzbrojonej w długą broń palną, berdysze i piki, oraz jazdy, głównie rajtarii, w niektórych przypadkach wyposażonej w zbroje (określanej jako „kiryśnicy”).

Siły korpusu J. Chmielnickiego zasadniczo nie odbiegały strukturą od typowych sił kozackich tego okresu. Operujący oddzielnie Kozacy J. Chmielnickiego to około 20 000-40 000 żołnierzy, w tym jazda wołoska ${ }^{8}$, i 20-30 dzial ${ }^{9}$. Bez

\footnotetext{
${ }^{6}$ Tak np. J. L a t i m e r, Deception in War, Warszawa 2008, s. 45, opis walk o Borne, Zakrzyce i Lutynię.

${ }^{7}$ A. H n iłk o, Wyprawa cudnowska, Oświęcim 2012 (przedruk wyd. z 1931), s. 70. Przywoływany autor pisze o ,puszczaniu strzał nawiasem”, który to sposób ostrzeliwania tłumaczy w sposób odpowiadający charakterystyce ognia stromotorowego, kierując się przekazem źródłowym: P. G o r d o n, Diary of Patric Gordon of Auchleuchris 1635-1699, vol. II, ed. D. Fedosov, Aberdeen 2009. Prawdopodobne jest też ostrzeliwanie stromotorowe przez łuczników wołoskich z korpusu J. Chmielnickiego w walkach z prawym skrzydłem polskim pod Słobodyszczami cf. J. L u b o m i r s k i, Wojna polsko-moskiewska pod Cudnowem odprawiona za panowania króla Jana Kazimierza pod wodza Stanisława Potockiego, wojewody krakowskiego i Jerzego Lubomirskiego, marszałka koronnego w roku pańskim 1660, oprac. A. Hniłko, Warszawa 1922, s. 80; Diaryusz wojny z Szeremetem i Cieciura pułkownikiem perejasławskim, która się odprawowała w meu wrześniu, październiku i listopadzie roku 1660, [w:] Ojczyste spominki w pismach do dziejów dawnej Polski, t. I, oprac. A. Grabowski, Kraków 1845, s. 156.

${ }^{8} \mathrm{Nie}$ była ona liczna - ok. 1200 koni, jednak od czasów początkowej fazy powstania B. Chmielnickiego jest jasne, że współdziałanie silnego otaborowanego zgrupowania piechoty kozackiej z dobrą jazdą (wówczas tatarską, następnie, w wyniku zmian sojuszy, Kozakom pozostało wsparcie ze strony jazdy wołoskiej, podobnej w taktyce do jazdy tatarskiej), nawet jeśli jest tylko jazdą lekką, stanowi groźną symbiozę dla wojskowości Rzeczypospolitej, jakkolwiek możliwą do pokonania, to zwykle dosyć krwawym kosztem.

${ }^{9}$ J. L u b o mirs k i, op. cit., s. 67.
} 
wątpienia więc stanowili dla Polaków dodatkowe zagrożenie, komplikując sytuację taktyczną ${ }^{10}$.

Cechą strony moskiewsko-kozackiej w czasie tej kampanii była przewaga ilościowa i jakościowa $\mathrm{w}$ zakresie artylerii różnych typów, choć trzeba także pamiętać, że posiadanie większej liczby dział o dużym i (zwłaszcza) bardzo dużym kalibrze nie musi w każdych warunkach być rozumiane jako przesłanka do uzyskania przewagi. Dzieje się tak w związku z przeznaczeniem dział najcięższych. Towarzyszyły one wojskom moskiewskim ze względu na pierwotny i jak pokazały dalsze wypadki - całkowicie nierealny zamiar wdarcia się głęboko na terytorium Rzeczypospolitej i oblegania kolejnych jej miast oraz twierdz ${ }^{11}$. Wojska Szeremietiewa traciły też sukcesywnie przewagę ilościową w artylerii: jak wywnioskował A. Hniłko ${ }^{12}$, w pierwszym szturmie na obóz moskiewski zdobyto trzy działa, w kolejnych dwu próbach odwrotu Szeremietiewa odpowiednio: siedem i 17, podczas kapitulacji zaś strona pokonana wydała jeszcze 24 działa. Pozwala to szeroko rozumieć dość nieprecyzyjne dane z Wojny polsko-moskiewskiej, w której wskazano tylko liczbę dział ciężkich (20) i polowych dział posiadanych przez Kozaków (6), a o innych działach źródło podaje, że było ich „wiele”" . Owo „wiele” musi oznaczać liczbę raczej co najmniej dwukrotnie przewyższającą liczbę dział ciężkich. Przyjmuję tak i ze względów kosztowych, i ilościowych, i techniczno-logistycznych oraz dlatego, że ogólna liczba dział zabranych przez Polaków w walkach i w czasie kapitulacji może być, z bardzo dużą dozą pewności, pomniejszona o pewną liczbę dział utraconych bezpowrotnie w wyniku walk (głównie ostrzału artylerii polskiej, ale też nierzadkich przy niskim poziomie metalurgii przypadków zużycia czy zniszczenia broni palnej w wyniku niewłaściwej eksploatacji). Wreszcie przeprawa nad Ibrem oraz obozowanie w początkowej fazie bitwy na podmokłym terenie pod Lubarem powinny, jak się wydaje, skutkować niebojową utratą dział (w transporcie).

Wybór kampanii cudnowskiej jako przedmiotu analizy współdziałania jest podyktowany trzema czynnikami.

Po pierwsze, staropolska sztuka wojenna znajdowała się wówczas na wyjątkowo wysokim poziomie zaawansowania. Było tak z kilku przyczyn. Znaczne siły reprezentowały zarówno wysoką różnorodność i typową, zoptymalizowaną w toku doświadczeń pierwszej połowy wieku XVII strukturę. Można je określić nie tyle jako symetryczne, bo przewaga jazdy była jeszcze wtedy cechą wyróżniającą SSzW, ile można tu mówić o siłach ukształtowanych harmonijnie.

${ }^{10}$ Starcia korpusem J. Chmielnickiego, jako należące do drugiej części kampanii (po dotarciu walczących do Cudnowa), nie stanowią przedmiotu niniejszych rozważań.

${ }^{11}$ Ramowe plany moskiewsko-kozackie i (związany z nimi) stan opatrzenia w uzbrojenie artyleryjskie charakteryzuje R. R o m a ń s k i, Cudnów 1660, Warszawa 2008, s. 17, 20 oraz 30-31.

${ }^{12}$ A. $\mathrm{H}$ n iłk o, op. cit., s. 37, przyp. 59.

${ }^{13}$ J. L u b o m ir s k i, op. cit., s. 67. 
Przewaga kawalerii polskiej nad innymi kawaleriami była na tyle duża i powtarzalna, że nie może dziwić znaczący udział tej broni w ogólnej liczbie wojsk i w puli ich finansowania. Silna i liczna jazda o dużej różnorodności i pewnej specjalizacji była elementem najpewniejszym i najbardziej wyróżniającym. Bez niego armia polska byłaby tylko mniej lub bardziej udanym powieleniem schematów ościennych państw, co w warunkach geograficznych, ekonomicznych i politycznych Rzeczypospolitej nie rokowało sukcesu.

Mniej liczna piechota jest jednak dostatecznie liczna i sprawna do wypełniania swych funkcji. W konfrontacji z cudzoziemskimi oddziałami typu zachodniego w służbie carskiej, piechotą kozacką i sotniami strzeleckimi, czyli zasadniczo z pełnym spectrum formacji piechoty europejskiej owego czasu, piechota polska oraz dragonia spieszona zwykle zdobywały przewagę taktyczną ${ }^{14}$.

Także artyleria polska, choć mniej liczna i o mniejszych wagomiarach, zyskiwała dużą skuteczność dzięki manewrowaniu i panowaniu nad przestrzenią, dzięki inicjatywie taktycznej jazdy i mocnej pozycji piechoty.

Staropolska sztuka wojenna występowała w formie, której opracowanie teoretyczne i doktryna liczyły sobie ok. 100 lat i nie traciły aktualności, a w szczytowym momencie aktywności znajdowało się już czwarte pokolenie wybitnych wodzów, uosabiane tu zwłaszcza przez hetmana polnego Jerzego Lubomirskiego ${ }^{15}$.

Tu warto przejść do drugiego czynnika, predestynującego daną kampanię do roli dobrego przedmiotu analizy. Chodzi o sztukę wojenną, ale tym razem w ujęciu nie materialnym, lecz podmiotowym - o osoby dowódców tej konkretnej kampanii, „władające” tymi metodami i środkami walki, swoistych dysponentów, wykonawców SSzW. Współdziałanie wojsk jest skomplikowanym procesem i jego należyta realizacja wymaga połączenia znajomości schematów z improwizacją, doświadczenia z innowacyjnością. Obecność dwu zdolnych wodzów, reprezentujących dwa pokolenia Polaków wychowanych na nieustających wojnach z rozmaitymi, często znacznie silniejszymi przeciwnikami stwarza dobre warunki do omawiania współdziałania bez konieczności biograficznych rozważań o przy-

${ }^{14}$ Ciekawe rozważania na temat proporcji jazdy i piechoty, który jest niejednokrotnie podnoszony przez rodzimych historyków wojskowości i często wręcz utożsamiający postęp ze zmniejszaniem liczby kawalerii względem pozostałych broni, zaprezentował niedawno R. Sikora. Autor wskazuje, że struktura i charakter armii Rzeczypospolitej w badanym okresie miały charakter nowoczesny, odpowiedni do zadań, choć odmienny od rozwiązań zagranicznych, zwłaszcza zachodnich. R. S i k o r a, Fenomen..., s. 132 i 144-145. Cf. wydana w tym samym roku aktualizacja przekrojowej analizy wojskowości polskiej drugiej połowy XVII w., zawierająca szczegółowe dane o liczebności rodzajów wojsk: J. W i m m e r, Wojsko polskie $w$ drugiej połowie XVII wieku, wyd. 2 poszerzone, Oświęcim 2013. Cf. też R.I. F r o s t, Potop a teoria rewolucji militarnej, [w:] Rzeczpospolita w latach potopu, red. J. Muszyńska, J. Wijaczka, Kielce 1996, s. 155 i 159.

${ }^{15}$ Podział na generacje wodzów jest umowny i może powodować liczne spory. Inny podział generacyjny wodzów z tego okresu historycznego przyjmuje np. T. K o r z o n, Dzieje wojen $i$ wojskowości w Polsce, Kraków 1912, t. II, rozdz. IV-V. 
czynach niedyspozycji, błędów, nielojalności, tchórzliwości, braku motywacji. Kadra dowódcza jest tu mechanizmem silnym i spójnym, nawet mimo animozji między dwoma hetmanami i różnicami pokoleniowymi między nimi. Przywództwo dwóch głównych wodzów (bo dowodzących dwiema równorzędnymi dywizjami w sytuacji, gdy powagę urzędu Potockiego równoważyła oczywista większa elastyczność Lubomirskiego) dopełniała wybornie reszta kadry, której symbolem może być postać zapowiadająca kolejną generację hetmańską - Jan Sobieski.

Czynnik trzeci to przeciwnicy i ich cechy. Zdyscyplinowana masa wojsk moskiewsko-kozackich ${ }^{16}$ nie była $\mathrm{z}$ całą pewnością przeciwnikiem łatwym, talent zaś jej głównodowodzącego pozwalał wyzyskać wszystkie jej atuty. Nie bez znaczenia jest też to, że w roku 1660 i Kozacy, i Moskwicini mieli pełną wiedzę ogólną o wojskowości polskiej, jak i - w wielu przypadkach - prywatne doświadczenie w walkach przeciw wojskom Rzeczypospolitej (niektórzy, zwłaszcza Kozacy, także po jej stronie). Wszelkie zatem sukcesy cząstkowe, jak i sukces definitywny kampanii stanowią wynik faktycznej wartości bojowej polskich wojsk i umiejętności ich wodzów. Są też tych wartości miernikiem, a z analizy można całkowicie wyłączyć element zaskoczenia, niewiedzy o charakterze i atutach przeciwnika, jakim była Polska.

Mamy tu więc do czynienia z przeciwnikiem licznym, dobrze uzbrojonym, mającym ambitne plany strategiczne i ostrożną, przemyślaną taktykę, do tego znającym wojska Rzeczypospolitej. $\mathrm{Z}$ drugiej strony z natury niewielka inwencja, niskie morale (przynajmniej w zakresie działań zaczepnych czy szerzej: inicjatywy, bo bronili się ci żołnierze z rozpaczliwą odwagą) czyniły z armii moskiewsko-kozackiej oraz z odsieczy J. Chmielnickiego przeciwnika, który jakkolwiek do pewnego stopnia pętał naturalne atuty polskie (zdolność do impetycznych i skomplikowanych manewrów, siła uderzenia, szybkość, zwrotność), to z całą pewnością nie był w stanie postawić Polaków w sytuacji zagrożenia i sprowadzić do roli biernej, defensywnej. Stąd zachowanie przez wojska Rzeczypospolitej na przestrzeni całej kampanii decydującego wpływu i - co najistotniejsze - swobody manewru. Walka mogła być mniej lub bardziej dla Polaków kosztowna. Zresztą czynniki te hetmani wywarzali dość rozsądnie, ale to SSzW królowała i nadawała ton całości działań. Moskwicini i Kozacy, mówiąc obrazowo, przez większość kampanii mogli tylko opóźniać lub w jakimś stopniu ograniczać swą nadchodzącą klęskę. Z tego właśnie powodu SSzW mogła być stosowana ze znaczną swobodą, zwłaszcza z pozostawieniem inicjatywy, nie stojąc tu jednak zarazem przed zadaniem banalnym, przed jakimś chwiejnym czy niesubordynowanym lub niedozbrojonym przeciwnikiem. Siła wojsk moskiewsko-kozackich oraz ich pasywna pozycja tworzyły sytuację, w której dowódcy i żołnierze Rze-

${ }^{16}$ Postawy kozackie w trudnych momentach cechowały problemy lojalnościowe, ale dyscyplina $\mathrm{w}$ walce nie chwiała się na tyle, by miało to istotny wpływ na jej przebieg. 
czypospolitej musieli włożyć wielki wysiłek w zwycięstwo, czyniąc to zarazem mądrze, stosując ekonomię sił, mieli jednak możliwość i warunki do wykazania najlepszych cech współdziałania. W bitwie polowej, podobnej do starcia pod Kircholmem, przeciwnik taki jak ten spod Cudnowa, zostałby najpewniej po prostu zniesiony lub przynajmniej zmieszany, rozdzielony, przez samą manewrującą kawalerię. Zresztą szereg decyzji Szeremietiewa, któremu nie można odmówić trzeźwości osądu, jak choćby pierwsze rzucenie szańców pod Lubarem, zaniechanie bitwy polowej tamże, następnie kosztowna defensywa, wskazują wyraźnie, że to zagrożenie impetem i zwrotnością jazdy polskiej było zdaniem rosyjskiego wodza najważniejsze. Groźne na tyle, że nie wahał się skazywać wojska na ostrzał, szarpanie podjazdami, brak wody, taktyczną i operacyjną bierność i porzucenie celów strategicznych, wreszcie na zmagania $\mathrm{z}$ bardzo dobrą polską piechotą, artylerią i dragonią, byle tylko nie próbować rozstrzygnięcia w polu. Z kolei w bitwie, w której ze względu na ogólną słabość sił, dyscypliny, położenia taktycznego czy przewage jazdy przeciwnika to wojska Rzeczypospolitej musiałyby przyjąć rolę defensywną ${ }^{17}$, nie byłoby możliwości obserwacji, a co za tym idzie - także analizy cech typowych SSzW. Dominacja inicjatywy polskiej daje więc dobre warunki do badania współdziałania wojsk Rzeczypospolitej i jej sojuszników. Walki taborowe natomiast nie były domeną SSzW, jednakże nie były też jej obce.

\section{Kutyszcze - pierwsze starcie, walki opóźniające}

Kutyszcze to uroczysko, na którym pierwszy raz doszło do istotnego kontaktu bojowego oddziałów polskich z awangardą armii moskiewsko-kozackiej. Najprawdopodobniej nastąpiło ono 14 września ${ }^{18}$. Nie będę stosował nazwy Kutyszcze na określenie miejsca późniejszego starcia z dnia 26 września $^{19}$. Aby lepiej zobrazować przyczynę, dla której do niego doszło (w szczególności celu przyświecającego Szeremietiewowi), określam je jako walki na drodze Lubar-Cudnów.

W walce tej występuje współdziałanie wysokomobilnych formacji walczących po stronie polskiej. Trzeba nadmienić, że Ł. Ossoliński zaprezentował umotywowany źródłowo pogląd, jakoby współdziałanie w wariancie pierwotnie założonym się nie powiodło. Miało ono zakładać obejście (odcięcie) kozackiej awangardy

17 Typowo obronną, jak w ciągu większości starcia pod Żółtymi Wodami, czy podjąć otaborowany odwrót, jak to uczyniono na linii Cecora-Mohylew lub pod Korsuniem.

${ }^{18}$ Wątpliwość może tu wprowadzać datowanie jednego ze źródeł - korespondencji hetmana J. Lubomirskiego. List opatrzony datą 14 września relacjonuje starcie, co pozwalałoby przyjąć, że doszło do niego 13 września. Jednakże większość branych pod uwagę źródeł, jak również badacze wskazują na datę 14 września. Kwestie sygnalizuję dla porządku, gdyż nie ma ona istotnego wpływu na analizowane współdziałanie.

${ }^{19}$ Jak to uczynił R. S i k o r a, Niezwykle bitwy i szarże husarii, Warszawa 2011, s. 141. 
przez chorągiew pancerną, a następnie jej skoordynowaną akcję z oddziałami $\operatorname{ordy}^{20}$. Starcie rozpoczęli Tatarzy, którzy zaatakowali awangardę wojsk Szeremietiewa, złożoną głównie z Kozaków. Zaskoczona awangarda kozacka poniosła straty, ale wprawienie w walkach z jazdą, w tym z Tatarami, pozwoliło pozostałym przy życiu Kozakom stawić opór przejściowy w taborze, a w konsekwencji dotrzeć do ściany lasu, który oczywiście dał im osłonę i zredukował do minimum takie walory lekkiej jazdy tatarskiej, jak manewrowość i szybkość ${ }^{21}$. W tym momencie nastąpiło współdziałanie. Jazdę tatarską wsparto jazdą lekką narodowego autoramentu (w celu zwiększenia efektywności realizacji zadań kawaleryjskich i zapewne także uzupełniania strat). Drugą dosłaną w to miejsce formacją byli dragoni jako siła oferująca te możliwości, którymi nie dysponowali lekkozbrojni kawalerzyści. Broń palna długa, podstawowy środek walki dragonów w spieszeniu, pozwalała na zwalczanie ukrytych w lesie Kozaków i wypieranie ich z utworzonych przez nich naprędce zasieków. W warunkach, w których drzewa, zarośla i zasieki nie dawały możliwości wykorzystania atutów lekkiej jazdy, konna piechota, czyli dragoni, była idealnym suplementem sił walczących na tym odcinku.

Po pierwsze, jak wspomniano, dragoni mogli się ścierać z przeciwnikiem w sposób uzupełniający to, jak walczyli kawalerzyści. Po drugie, mogli zjawić się tam szybciej od piechoty, nadążyć w rozsądnym czasie za jazdą ${ }^{22}$. Po trzecie wreszcie, nie tylko dragoni wspierali jazdę - działało to też w drugą stronę. Obecność jazdy tatarskiej i lekkiej jazdy koronnej na skraju lasu lub w jego pobliżu ograniczała możliwość przedarcia się odciętych Kozaków do swoich głównych sił, tj. do nadciągającego taboru, oraz możność przyjścia im z pomocą przez mniejsze oddziały jazdy moskiewskiej. W celu ratowania tej pozycji kozackiej przed napierającymi na nią skutecznie dragonami Szeremietiew musiałby pchnąć oddział na tyle szybki, więc kawaleryjski, by zdążyć uratować Kozaków, a zarazem na tyle silny, by przebił się do nich przez operujące po drodze siły tatarskie

${ }^{20}$ Ł. O s s o 1 i ń s k i, Cudnów-Stobodyszcze 1660, Zabrze 2006, s. 40.

${ }^{21}$ Inaczej, znacznie bardziej aprobująco ocenia ten etap walk R. R o m a ń s k i, op. cit., s. 41-43.

${ }^{22}$ Sformułowanie „nadążyć w rozsądnym czasie” nie jest tu dodatkiem czy ozdobnikiem, gdyż możliwości owego nadążania przez dragonów za jazdą, zwłaszcza lekką i na dobrych koniach kawaleryjskich, były mocno ograniczone jakością koni, tzw. podjezdków, co do zasady o wiele wolniejszych niż konie jazdy. Jest to oczywiście stwierdzenie o charakterze ogólnym, jednak oparte na dużym statystycznym prawdopodobieństwie i na szacunkach co do ekonomicznego zaplecza armii. Skoro koni dobrych nie zawsze starczało nawet dla jazdy ( $c f$. częste w źródłach wskazanie, że dana chorągiew była „na koniach dobrych”, ergo inne formacje takich nie miały, skoro narracje czynią takie rozróżnienie), to dragoni, którzy koni używali głównie do przemieszczania się, ale już nie do walki, więc nie musieli na nich np. ścigać jednostek wroga czy szarżować, zapewne otrzymywali konie najgorsze. Niemniej różnica w szybkości wejścia do akcji dragonów w stosunku do piechoty była kolosalna. Weźmy pod uwagę, że dragoni walczą w pierwszym starciu z najbardziej wysuniętym oddziałem kozackim, a tymczasem większość piechoty, jak twierdzi A. Hniłko, nie zdążyła w okolicę tego starcia... do rana następnego dnia. A. H n ił k o, op. cit., s. 47. 
i lekkiej jazdy koronnej, wykonującej działania izolujące. Biorąc pod uwagę dwa lustrzane czynniki: z jednej strony niską jakość i stosunkowo niską liczebność jazdy moskiewskiej oraz z drugiej strony jakość i ilość jazdy wojsk Rzeczypospolitej i Tatarów, należy przyjąć, że los Kozaków był przesądzony. Tak też było. Kozacy zostali wyparci z lasu przez spieszonych dragonów, następnie wybici przez lekką jazdę ${ }^{23}$. Współdziałanie ognia dragonów i manewrowości jazdy lekkiej nie tylko pozwoliło na tym wstępnym etapie walk osiągnąć ważny cel (pozbawienie taboru wojsk przeciwnika jego awangardy), lecz także - co bardzo istotne $\mathrm{w}$ świetle dalszych wyzwań - zrobiono to $\mathrm{z}$ niewielkimi chyba stratami i brakiem spadku morale, skoro w następstwie starcia jazda tatarska i choraggwie lekkie rzuciły się jeszcze na czoło głównego taboru ${ }^{24}$. Najważniejszym efektem tego ataku, noszącego cechy współdziałania, było stworzenie sytuacji, w której z jednej strony wojska moskiewsko-kozackie doznały spowolnienia i pojawiło się $\mathrm{w}$ nich pewne zamieszanie, $\mathrm{z}$ drugiej strony wojska koronne mogły kontynuować marsz w sposób niezakłócony i osiągnąć dogodne pozycje pod Lubarem.

Na krytykę zasługuje brak współdziałania ze strony Tatarów w pierwszej fazie starcia. Nie przekreśla on jednak efektywności ordyńców, a nawet pewnej ich ofiarności (dalsze uderzenie na czoło głównego taboru moskiewskiego). Wspólne uderzenie $\mathrm{z}$ chorągwią pancerną mogło istotnie przyspieszyć efekt rozgromienia całej awangardy kozackiej bez mozolnego wypierania jej z lasu ${ }^{25}$.

Reasumując, siły polskie prawidłowo zaplanowały współdziałanie. Nie mogły go zrealizować według pierwotnego planu wobec niekontrolowanej postawy tatarskiego sojusznika. Zwycięstwo udało się jednak osiągnąć wspólnymi siłami Polaków i Tatarów wskutek przeprowadzonego ad hoc współdziałania. Pokazuje to w praktyce, jak właściwie skomponowaną pod względem podziału ról i wzajemnego uzupełniania się strukturą były siły Rzeczypospolitej i jej sojusznika. Nawet ewidentne zamieszanie, w konsekwencji zarzucenie pierwotnego planu, nie przekreśliło możliwości współdziałania.

\section{Pierwsze szturmy taboru moskiewsko-kozackiego}

Dnia 15 września rozpoczął się drugi etap walk pierwszej części tej kampanii, ogólnie określany jako walki pod Lubarem. Okres ten sięga do dnia 26 września, tj. do tzw. pierwszego odwrotu Szeremietiewa. Obie strony cechowała ostrożność. Wódz moskiewski nie wykazywał jednoznacznego dążenia do rozstrzygnięcia bitwy w polu, choć wedle jego wiedzy wojska polskie znacznie ustępowały liczebnie jego armii. O rzeczywistym stanie sił polskich Szeremie-

\footnotetext{
${ }^{23}$ Ibidem.

${ }^{24}$ Diaryusz ..., t. I, s. 145-146.

${ }^{25}$ Ł. O s s o 1 i ń s k i, op. cit., s. 40.
} 
tiew dowiedział się najprawdopodobniej 15 września. Ten wybitny moskiewski dowódca miał świadomość, że w bezpośrednim starciu nawet mniej liczna jazda polska ma ogromną przewagę nad jego wojskami. Szeremietiew wolał narazić swoje i kozackie siły na ostrzał artyleryjski, brak wody, a także rezygnację z głównych celów strategicznych kampanii i celów operacyjnych oraz oddanie inicjatywy taktycznej, byle uniknąć starcia w otwartym polu z armią Rzeczypospolitej. Moskwicin przyjął pozycję bierną. Metoda taka, znana od czasów Gustawa II Adolfa Szwedom ${ }^{26}$, ale też Kozakom ${ }^{27}$, mogła się sprawdzić jako środek przejściowy w warunkach dobrej aprowizacji, przynajmniej dostępu do wody pitnej, i nadziei na odsiecz (lub celowego wiązania sił polskich, by dać wolną rękę innym siłom). W celu realizacji celów przyjętych w tej sytuacji przez Szeremietiewa musiałoby nastąpić ogólne współdziałanie jego sił z nadciągającymi oddziałami J. Chmielnickiego. Jak się przekonamy, takie współdziałanie nie urzeczywistniło się w formie ścisłej, a przybliżenie się korpusu Chmielnickiego dało niewiele.

Z kolei hetmani polscy, Potocki i Lubomirski, podjęli decyzje wskazujące $\mathrm{w}$ pierwszej kolejności na stosowanie zasady ekonomii sił i docenianie roli współdziałania. Mimo dysponowania liczną jazdą o świetnym morale, nie zdecydowali się na uderzenie, gdy dostrzegli główne siły przeciwnika we wczesnych godzinach porannych. Nie uczynili tego także w obliczu nieukończonych jeszcze prac fortyfikacyjnych obozu moskiewsko-kozackiego ${ }^{28}$. Przeważyło oczekiwanie na warunki optymalne dla współdziałania wszystkich rodzajów wojsk, tj. na przybycie piechoty i artylerii polskiej, które dopiero ściągały w okolice walk ${ }^{29}$. W działaniu na tak dużą skalę współdziałanie jazdy z dragonami, użytymi ewentualnie w miejsce piechoty, nie zostało uznane za celowe. Choć szybkość i gwałtowność wobec przeciwnika o słabym morale i w pełni nieprzygotowanego, będącego w fazie rzucania szańców, mogłyby się wydać tyleż atrakcyjne, co zgodne z ogólnie dynamicznym charakterem SSzW, to należy pamiętać, że owa gwałtowność działań nie była w sztuce wojennej I Rzeczypospolitej jakimś kaprysem czy sumą cech osobowości wodzów, ale postępowaniem pragmatycz-

${ }^{26}$ Cf. opinie Krzysztofa Radziwiłła: K. Radziwitt do Broniewskiego; 30 X 1621; K. Radziwitt do króla; 24 XI 1621; K. Radziwitt do króla; 27 IX 1621; K. Radziwitt do króla; 30 X 1621; K. Radziwitt do Wacława Leszczyńskiego; 30 X 1621; K. Radziwilt do Leona Sapiehy; 17 VI 1622, [w:] Księcia Krzysztofa Radziwilta hetmana polnego Wielkiego Księstwa Litewskiego sprawy wojenne i polityczne 1621-1632, Paryż 1859, s. 85, 91, 96, 99, 107, 118, 214, 238.

27 G. B e a u pla n, Description d'Ukraine, qui sont plusieurs provinces du Royaume de Pologne. Contenues depuis les confins de la Moscovie, insques aux limites de la Transilvanie, Paris, 1661, s. 21 in fine, https://archive.org/details/descriptiondelv00beaugoog (dostęp: 10 VI 2016).

${ }^{28}$ Krytycznie szanse powodzenia tak wczesnego generalnego ataku ocenia Ł. O s s o li ń s k i, op. cit., s. 43.

${ }^{29}$ A. H n iłk o, op. cit., s. 47-48. 
nym, choć ryzykownym, często podejmowanym w obliczu braku czasu, warunków i środków na dłuższą walkę. Jednak nawet hetman Stanisław Żółkiewski ze swymi szczupłymi siłami pod Kłuszynem zaczekał na zebranie się przynajmniej części chorągwi z rozciągniętego szyku marszowego zamiast tylko pierwszymi chorągwiami uderzać na obóz Moskwicinów i ich sprzymierzeńców. Także tu, w sytuacji ogólnego zapanowania nad ruchami przeciwnika, polskie wojska czekały na sytuację, gdy możliwe będzie pełnowartościowe i pełnoskalowe współdziałanie. Było to tym bardziej korzystne, że żołnierze Moskwy i Kozaczyzny, jakkolwiek skłonni do załamania morale i masowych dezercji w polu, przejawiali jednak wielką, rozpaczliwą wręcz waleczność w sytuacji obrony. Atak na taką desperacką stłoczoną masę mógł się powieść, ale oznaczałby walkę w ścisku $\mathrm{z}$ wielkimi grupami piechoty wroga, co redukowałoby walory manewrowe doborowych formacji Rzeczypospolitej i mogło generować dodatkowe straty. Wydarzenia $\mathrm{z}$ dalszego etapu tej samej kampanii, mianowicie walki $\mathrm{z}$ korpusem J. Chmielnickiego pod Słobodyszczami, dobitnie pokazały, jak wielkie zagrożenie może stanowić zmotywowana strachem, rozpaczliwie walcząca piechota kozac$\mathrm{ka}^{30}$. Zasada ekonomii sił $\mathrm{w}$ staropolskiej sztuce wojennej była daleka od straceńczości. Mogło się wydawać, że z walnego szturmu na razie zrezygnowano wobec tego, że przeciwnik zachowywał się statycznie, okopywał i umacniał swe pozycje, nie dawał się wywabić harcownikom i był zdecydowany bronić się $\mathrm{w}$ taborze z wykorzystaniem pobliskiego wzgórza jako stanowiska dla baterii.

Współdziałanie stało się możliwe dnia następnego, 16 września, gdy po chwiejnej próbie wyjścia w pole większe siły moskiewsko-kozackie wróciły do warownego obozu, pozostawiając pobliskie wzgórze $\mathrm{z}$ jedną półbaterią dział i kilkuset piechurami ${ }^{31}$.

Współdziałanie wojsk polskich polegało na użyciu jazdy w dwu rolach. W pierwszej fazie jazda wyparła oddziały przeciwnika ze wzgórza, robiąc miejsce dla dragonii.

Niewątpliwie błędne było pozostawienie dragonów bez osłony kawalerii. Ta bowiem, poza pełnieniem zadań ofensywnych, występowała w SSzW jako osłona piechoty, zwłaszcza że tradycyjnie polskie oddziały piesze (poza brakiem koni podobne wyposażeniem do dragonii) miały charakter strzelczy, pikinierzy stanowili w nich element strukturalnie obcy, choć ich liczba bywała znaczna.

${ }^{30}$ Przekazy źródłowe są zgodne co do wyjątkowo dramatycznego przebiegu walk pod Słobodyszczami po wdarciu się jazdy polskiej do obozu kozackiego - cf. Diaryusz wojny z Szeremetem i Cieciura pułkownikiem perejresławskim, która się odprawowała w meu wrześniu, październiku i listopadzie roku 1660, [w:] Ojczyste spominki..., s. 156; J. L u b o m i r s k i, op. cit., s. 81; W. K o c h o w s k i, Historya panowania Jana Kazimierza, t. I, wyd. E. Raczyński, Poznań 1859, s. 94; S. L e s z c z y ń s k i, Potrzeba z Szeremetem hetmanem moskiewskim i Kozakami, Kraków 1661, s. 88.

${ }^{31}$ J. L u b o m i r s k i, op. cit., s. 42. 
Z pewnością jednak dragoni, polegający głównie na broni palnej, nie mogli sami utrzymać wzgórza w obliczu kontrataku jazdy moskiewskiej. Ich pozostawienie można zatem częściowo usprawiedliwiać. Na tle niechętnego wykorzystywania jazdy w wojskowości moskiewskiej i ogólnej przewagi wojsk jezdnych armii polsko-tatarskiej od początku kampanii jaskrawo rysowała się wyjątkowo zachowawcza postawa dowództwa moskiewskiego w ogóle. Można zatem stwierdzić, że rozpaczliwe próby utrzymania wzgórza, leżącego przecież poza obrębem taboru, w którym trzymał się Szeremietiew z Cieciurą, stanowiły wyjątek. Wysłanie zaś jazdy moskiewskiej w celu odbicia wzgórza było posunięciem tak krótkowzrocznym, że nie mogło być przewidziane w wykonaniu racjonalnego i doświadczonego wodza, jakim niewątpliwie był Szeremietiew ${ }^{32}$. Tezę swą popieram choćby postępowaniem tego samego wodza wobec nadwątlonych walką sił piechoty Niemirycza i idących im w odsieczy pancernych Sobieskiego pod Cudnowem 28 września, kiedy moskiewski wódz nie miał śmiałości uderzać na polskie oddziały w otwartym polu (ale w bliskości moskiewskiego obozu). Wyraźnie ostrzegał przed tym dowódca jednej z trzech dywizji moskiewskich - Kozłowski ${ }^{33}$.

Po próbie przejęcia wzgórza z powrotem przez przeciwnika regiment dragonów wzmocniono kombinowanym ad hoc zespołem zadaniowym $\mathrm{z}$ różnych formacji piechoty oraz oddziałami jazdy. W celu utrzymania wzniesienia ta ostatnia współdziałała z piechotą w działaniach defensywnych. Jazda polska przeciwdziałała obejściu piechoty na wzgórzu przez jazdę moskiewską oraz jej wyparciu. Jest to więc druga rola, w jakiej jazda wystąpiła we współdziałaniu. Oddziały jazdy polskiej parowały uderzenia jazdy moskiewskiej.

W konsekwencji utrzymania istotnego taktycznie wzgórza i poddania obozu moskiewsko-kozackiego dotkliwemu ostrzałowi artyleryjskiemu nastąpiło natarcie sił obu dywizji polskich oraz ordy tatarskiej na ten obóz. Dywizja Potockiego walczyła na lewym skrzydle wojsk Szeremietiewa, atakując moskiewską część warownego obozu. Lubomirski nacierał na część kozacką w sposób metodyczny, wypierając z pola za wały, do obozu, wysunięte zgrupowania piechoty kozackiej.

${ }^{32}$ Rozważania, czy takie działanie stanowiło przejaw jakiejś niesubordynacji, samowoli dowódcy niższego szczebla lub spontanicznej akcji oddziałów moskiewskich, pozostają w sferze spekulacji i raczej poza nią nie wyjdą - przekaz żadnego z analizowanych źródeł nie wskazuje, by oddziały moskiewskie walczyły o wzgórze bez zgody naczelnego dowództwa. Oddolna inicjatywa ofensywna nie cechowała też armii moskiewskiej jako takiej.

${ }^{33} C f$. W. K o c h o w s k i, op. cit., s. 95. Kozłowski wyróżniał się realizmem na tle innych dowódców strony moskiewsko-kozackiej. Już u progu kampanii sceptycznie oceniał możliwość realizacji planów inwazji w głąb Polski, argumentując, że wojska polskie bardzo górowały nad moskiewskimi i kozackimi poziomem wyszkolenia i efektywnością w realnej walce $-c f$. $\mathrm{R}$. $\mathrm{R}$ o $\mathrm{m}$ a ń s k i, op. cit., s. 17. Podejście takie bardzo wyraźnie kontrastowało z groteskowym brakiem realistycznej oceny i przechwałkami Cieciury i Szeremetiewa $-c f$. W. K o c h o w s k i, op. cit., s. 82. 
Użycie w polu jazdy pozwalało na podciągnięcie i uszykowanie piechoty oraz zachowanie jej sił (i środków, bo np. dostarczanie w czasie bitwy amunicji pod wały wroga musiało być trudne, toteż jego unikanie było wskazane) na szturm wałów obozowych. Wystąpiła tu pewna sekwencja zdarzeń ${ }^{34}$. Moim zdaniem są to działania, które można nazwać współdziałaniem oddolnym, improwizowanym. Na skutek samodzielnych manewrów, głównie pozorowanych odwrotów i ataków jazdy tatarskiej, w okolicy wałów kozackich powstało zamieszanie wywołane próbami kontrakcji piechoty kozackiej, która wypuściła się w pościg za symulującym odwrót przeciwnikiem. W wyniku tego fermentu najpierw Tatarzy, a potem lekkie znaki polskiej jazdy uderzyli na wyrwę w obronie. Oddziały polskiej jazdy lekkiej współdziałały więc w tym momencie spontanicznie z jazdą tatarską. To skumulowanie działań podobnych co do roli taktycznej formacji chwilowo zwiększyło skuteczność ataku, ale też dały o sobie znać ograniczenia tego jazdy lekkiej w dłuższej walce na wałach i w obozie, gdzie nie mogła ona wykorzystać swoich atutów. Przerwanie umocnień bywało trudne, toteż - gdy się już powiodło - budziło w doświadczonych żołnierzach naturalny w tym przypadku odruch chwytania okazji, walki o to, by jej nie zmarnować, by nie trzeba było ponownie łamać umocnień i rwać taboru za cenę strat własnych. Rozumiejąc konieczność uzupełnienia sił atakujących i wsparcia ich ogniem broni palnej, niektórzy oficerowie na własną rękę podjęli się współdziałania z jazdą lekką, która jako pierwsza wdarła się w wyłom w obronie kozackiej. Nie można zaprzeczyć, że w rozumieniu punktowej przewagi taktycznej i potrzeby chwili był to odruch słuszny. Wiadomo o dwu zgrupowaniach dragonów i jednym połączonym zgrupowaniu piechoty, które podążyły za lekką jazdą na szturm. Nie był to szturm walny, a siły spontanicznie poderwane do ataku, działające oddolnie były za słabe, by samodzielnie wywalczyć zwycięstwo. Pewne jest, że nastąpiło tu współdziałanie i że w sferze decyzyjnej miało charakter oddolny. Dowodzący tym odcinkiem frontu J. Lubomirski nie zdecydował się na wydanie rozkazu do szturmu wyrwy w obronie Kozaków $^{35}$. Wspomniane oddziały dragonii i piechoty w końcu się cofnęły, zdobywając jednak dwa lub trzy działa ${ }^{36}$.

Kolejne większe walki miała wszak podjąć strona polska dopiero wówczas, gdy tabor ponownie ruszy po wielu dniach trwania $w$ miejscu ${ }^{37}$. Plany wielkiego szturmu polskiego 16 września neguje w swej pracy Ł. Ossoliński. Przywoływany autor twierdzi, że w zamyśle hetmanów nie było miejsca na atak generalny. Odrzuca więc podejście J. Wimmera i R. Romańskiego, którzy rezultat starcia

${ }^{34}$ A. H n i $\nmid$ k o, op. cit., s. 51.

${ }^{35}$ Memorabilis Victoria de Szeremetho etc. ad Cudnoviam reportata Anno Domini MDCLX. V Novembris. - Scripta per Revezendura Joannem Zielenievicium etc., Kraków 1668, s. 56.

${ }^{36}$ Opisy tego etapu walk $c f$. P. G o r d o n, op. cit., vol. I, s. 217 i n.; Memorabilis..., s. 55.

${ }^{37}$ Tak: Ł. O s s o 1 i ń s k i, op. cit., s. 45. 
uznali za fiasko polskich planów szturmu generalnego. Stwierdzenie to Ossoliński motywuje zachowaniem głównych sił piechoty, które w swej masie nie przystąpiły do ataku. Wydaje się, że prawda leży pośrodku. Nie wiadomo, czy obydwaj hetmani wykluczali szturm. Hetman Lubomirski surowo zabronił atakującym dalszych działan ${ }^{38}$. Hetman Potocki jedynie cofnął swe oddziały poza zasięg nieprzyjacielskiego ognia, gdy „kilkunastu z piechoty postrzelono”39. Jak zatem połączyć dwa stany rzeczy: duże zaangażowanie hetmanów, wyjście na pierwszą linię, dowodzenie wydzielonymi oddziałami walczącymi pod umocnieniami okopanego taboru moskiewsko-kozackiego oraz całkowity brak woli atakowania (wskazywana przez Ł. Ossolińskiego) lub przynajmniej niechęć Lubomirskiego do ataku generalnego (sugerowana przez A. Hniłkę)?

Odpowiedzią może być przypuszczenie, że hetmani usiłowali współdziałać, chcieli skoordynować uderzenie, tak by żaden z nich nie miał przeciw sobie całej masy zamkniętych w obozie wojsk przeciwnika, lecz by Kozacy i Moskwicini byli zmuszani do walki i na swym lewym i prawym skrzydle. Tłumaczy to podtrzymywanie walk przez obydwu hetmanów. Losy starcia potoczyły się najwyraźniej inaczej.

Obrona kozacka osłabła po nieudanej wyprawie Zaporożców, zniweczonej przez wspomniany błyskawiczny kontratak tatarski, wsparty przez lekką jazdę polską. Gdy do wyrwy w obronie ruszyły dalsze oddziały piechoty i jazdy polskiej, Lubomirski je powstrzymywał. Skrzydło moskiewskie, atakowane przez Potockiego, nie zostało rozerwane, powodzenie Lubomirskiego było odosobnione, punktowe ${ }^{40}$.

Hetmanowi polnemu trudno zarzucać błąd. Sąsiednie natarcie hetmana wielkiego Potockiego nie mogło go posiłkować, bo nie zagroziło dostatecznie fortyfikacjom moskiewskim. Oznaczało to, że choć duża część sił przeciwnika jest, w warunkach obrony wzdłuż umocnień, wiązana walką przez obie dywizje polskie i przez Tatarów (więc siły broniących się były rozciągnięte wzdłuż całej linii ataku), to jednak w wyniku punktowego wdarcia się do obozu te ściśnięte w nim oddziały atakujących natykałyby się na opór Kozaków i Moskali, którzy całą swą energię obróciliby na bardziej dla nich niebezpieczne, bo bliższe zagrożenie. To bardziej bezpośrednie zagrożenie ściągnęłoby najpewniej na siebie całe masy tych, którzy nawet jeśli nie przykładali największego oddania do obrony linii fortyfikacji obozu, to postawieni w sytuacji obrony własnego życia, zdobyliby się na wysiłek największy. Dzięki uniknięciu walk w takich warunkach dowództwo polskie zastosowało zasadę ekonomii sił, zminimalizowało straty własne ${ }^{41}$. Za-

${ }^{38}$ A. H n iłk o, op. cit., s. 50-51; R. R o m a ń s k i, op. cit., s. 62-63.

${ }^{39}$ Diaryusz..., s. 159.

${ }^{40}$ A. H n ił k o, op. cit., s. 50-51; R. R o m a ń s k i, op. cit., s. 60-61.

${ }^{41}$ Journal de ce qui c'est passe entre l'armée des Polonais et Celle des Moscovites depuis le 9 Septembre dernier; [w:] Pisma do wieku i spraw Jana Sobieskiego, t. I. cz. 1, oprac. F. Kulczycki, Kraków 1880; Memorabilis Victoria..., s. 55; P. Gord o n, op. cit., vol. I, s. 217-218. 
równo przykład Ochmatowa w roku 1655, jak i (choć mniej klarowny co do ogótu przyczyn) kosztowny dla strony polskiej triumf pod Kumejkami w 1637 r. czy zaciekła obrona samych Polaków w taborze pod Żółtymi Wodami zapowiadały te zagrożenia, które praktyka wojenna miała potwierdzić po upływie $10 \mathrm{dni}$ w ciężkich, zmasowanych walkach na początku szlaku Lubar-Cudnów, nad Ibrem, zwłaszcza zaś trzy tygodnie później w morderczych zmaganiach jazdy polskiej z otaborowanymi Kozakami Chmielnickiego pod Słobodyszczami. W każdym razie Lubomirski nie wydał rozkazu do szturmu. Nie doszło więc w tym dniu do planowego współdziałania większych sił. Nastawał dłuższy okres, noszący cechy oblężenia. Zlokalizowany teraz bliżej niż poprzednio obóz polski blokował ruch taboru, ugrzęzłego we własnych umocnieniach i cierpiącego z braku paszy dla koni. Polacy i Tatarzy, korzystając z przewagi swej jazdy, blokowali dalsze wycieczki Moskwicinów i Kozaków. Czas był po stronie Polaków. Słabnące morale przeciwników i chwiejna postawa Kozaków mogły dawać nadzieję na powodzenie oblężenia. Brak współdziałania między korpusem Szeremeta a wsparciem idącym od Jerzego Chmielnickiego stawiał przeciwników Polski w gorszej sytuacji.

Mądra wydaje się więc decyzja o zaniechaniu kontynuowania działań, w których niemożliwe było uzyskanie symetrii i aktywne współdziałanie z siłami Potockiego, wciąż związanymi walką z oddziałami moskiewskimi.

Siłę ducha bojowego strony polskiej najlepiej obrazuje sytuacja, w której hetman Lubomirski musiał powstrzymywać swych żołnierzy od ataku na obóz moskiewsko-kozacki, mimo że przeciwnik był przecież liczny i dobrze uzbrojony.

Trudno to spontaniczne działanie żołnierzy poddać jednoznacznej krytyce, sama zaś odwaga zasługuje na najwyższe uznanie. Nie doszło też do jakiegoś ogólnego zachwiania dyscypliny, groźnego dla całej armii.

\section{Marsz Lubar-Cudnów - walki z taborem w ruchu}

W dniu 26 września Szeremietiew podjął jedyną możliwą, jak się wydawało, decyzję. Ruszył taborem z całością swych sił w kierunku Cudnowa. Dywizja Potockiego spowalniała go wespół z Tatarami, dywizja Lubomirskiego - ścigała. W czasie pościgu na trasie Lubar-Cudnów, w okolicach wspomnianego uroczyska Kutyszcze, doszło do pierwszego na tym etapie walk współdziałania formacji wojsk Rzeczypospolitej na większą skalę.

Co istotne, mimo powolności taboru moskiewsko-kozackiego i raczej statycznego i długotrwałego przebiegu walk, po raz kolejny kluczową rolę odegrała jazda polska. Jedynie ona, wobec zaskoczenia, jakie wywołał wymarsz taboru

\footnotetext{
Wszystkie te źródła podają straty moskiewsko-kozackie kształtujące się wobec strat polskich w proporcji co najmniej 1:20 (u Gordona nawet 1:30, ale bez podania strat tatarskich), wskazują też na straty korpusu moskiewsko-kozackiego w artylerii wynoszące od dwóch do trzech dział.
} 
moskiewsko-kozackiego, była zdolna do marszu na tyle szybkiego, by utrudniać przemieszczanie się wojsk Szeremietiewa i Cieciury. Piechota i artyleria nie poruszały się dość szybko i gdyby to one stanowiły siły dominujące w armii polskiej, pościg mógłby trwać wiele dni i nie przynosić istotnego kontaktu bojowego. Historia walk w tej części świata daje zaś jak najgorsze prognozy dla każdej armii, która długo i uparcie brnie za cofającym się przeciwnikiem. Bez jazdy Polacy zostaliby z pewnością wciągnięci w bezproduktywny pościg, który przerzedziłby ich siły i wystawił na odcięcie ${ }^{42}$.

Jazda przyjęła na siebie ciężar walk z ruchomą twierdzą, jaką stanowił tabor. Trzeba też podkreślić, że nawet ogół jazdy polskiej nie dorównywał liczebnie siłom Moskwicinów i Kozaków ukrytych za taborem i wspartych rozmieszczoną na nim artylerią. Do tego trzeba dodać, że w początkowej, porannej fazie tego etapu walk nie została użyta cała jazda, która była w dyspozycji hetmanów. Prawe skrzydło wojsk polskich, czyli dywizja Potockiego, nie mogło atakować taboru, póki przedzierał się on przez las ${ }^{43}$. Przypomnijmy, że to w tej dywizji było najwięcej jazdy polskiej ${ }^{44}$.

Z dywizji J. Lubomirskiego wydzieliła się najpierw jedna chorągiew husarska pod dowództwem rtm. Wilczkowskiego, w ślad za nią poszła druga, pod rtm. Wyżyckim. Wiadomo, że polscy husarze (w liczbie ok. $140^{45}$ ) walczyli tu w warunkach ogromnej dysproporcji sił na swą niekorzyść. Oszacowanie dokładnych sił, z jakimi przyszło nawiązać bezpośredni kontakt bojowy, sprawia trudności choćby ze względu na bliskość taboru i fakt, że jednostki wystawione na szarżę w momencie jej rozpoczęcia mogły zarówno zbiec za tabor, jak i uzyskać wsparcie nowo dosłanych jednostek $\mathrm{z}$ taboru lub przynajmniej wsparcie ogniowe jego obsady. Wiadomo jednak, że nawet gdyby dla sił moskiewsko-kozackich przyjąć najniższe z szacowanych stanów liczebnych i gdyby nie otrzymały one żadnego wsparcia, w tym ogniowego od taboru (co byłoby naruszeniem podstaw współdziałania $\mathrm{z}$ taborem), to i tak ich siły stanowiły więcej niż dziesięciokrotność sił polskich. Przeciwnik dysponował dwoma szwadronami jazdy moskiewskiej typu niemieckiego, określanej jako „kiryśnicy”. Relacja Leszczyńskiego akcentuje ich kompletne wyposażenie, w tym zbroje i broń palną. Wedle różnych szacunków było ich od 600 do 1000 . Resztę ariergardy zaatakowanej przez husarię stanowił pułk kozackiej piechoty, szacowany na 1000-2500 ludzi.

${ }^{42} C f$. ocena trudności marszowych w armii moskiewsko-kozackiej: W. K o c h o w s k i, op. cit., s. 88; A. H n i $1 \mathrm{k} \mathrm{o,} \mathrm{op.} \mathrm{cit.,} \mathrm{s.} 53$ in fine.

${ }^{43}$ Diaryusz..., s. 150; cf. J. L u b o m i r s k i, op. cit., s. 54.

${ }^{44}$ Uformowanie ogólne sił moskiewsko-kozackich w marszu na drodze Lubar-Cudnów opisują: P. G o rd o n, op. cit., vol. II, s. 59; J. L u b o m i r s k i, op. cit., s. 51-53 i 56; S. L e s z c z y ń s k i, op. cit., s. 32-33 i 74-75; C.H. H o 1 s t e n, Przygody wojenne 1655-1660, oprac. T. Wasilewski, Warszawa 1980, s. 57; W. K o c h o w s k i, op. cit., t. II, s. 88.

${ }^{45}$ R. S i k o r a, Niezwykte..., s. 141. 
Wiadomo, że do szarzy husaria wchodziła etapami. Najpierw atakowała chorągiew pod dowództwem Wilczkowskiego, następnie podkomendni Wyżyckiego. Wiemy też, że husarii towarzyszyli dragoni, ale źródła nie charakteryzują ich roli. Nie wiemy więc, czy nastąpiło współdziałanie przez np. osłonę ogniem zaporowym husarii przed ostrzałem $\mathrm{z}$ wozów taborowych albo też zwiększenie efektu uderzenia husarii przez ostrzelanie przeciwnika, na którego szarżowali kopijnicy. Wreszcie wiadomo, że do walki przystąpiły później inne oddziały kawaleryjskie: regiment rajtarii Lubomirskiego pod komendą pułkownika de Oedta i trzy chorągwie jazdy pancernej. Choć niewiele wiemy o działaniach tych formacji, to wyraźnie widać, że niewielkim siłom uderzającym na broń białą (czyli wspomnianym dwóm chorągwiom husarzy pod dowództwem Wilczkowskiego i Wyżyckiego) towarzyszyły jednostki o charakterze strzelczym (dragoni, rajtarzy) bądź uniwersalnym (pancerni). Wskazuje to na potencjał współdziałania przez uzupełnianie się formacji (strzelcy i kopijnicy) z dodatkową możliwością współdziałania przez wsparcie w walce na broń białą walczących husarzy przez pancernych (także rajtarów).

Szarża przyniosła zwycięstwo nad ariergardą moskiewsko-kozacką. Jazda przeciwnika została rozbita, piechota przerzedzona i zepchnięta do lasu, gdzie podobnie jak podczas pierwszych walk w okolicach Kutyszcza, w warunkach leśnych nie marnowano potencjału jazdy, wysyłając na niedobitki kozackiej piechoty oddziały spieszonych dragonów. Radosław Sikora wskazuje, że po uderzeniu na jazdę moskiewską, a następnie na piechotę kozacką husarze dostali się pod ostrzał z taboru, który w ten sposób wspierał pozostałych przy życiu Kozaków ${ }^{46}$.

Atak przyniósł oderwanie pozostałej części ariergardy i uwięzienie jej na pozycjach na skraju lasu. Ze względu na to, że nieopodal nadciągały już oddziały piechoty i artylerii, które podążały za taborem i jazdą, mogły one wzmocnić nacisk na ukrytych w lesie Kozaków. Użyto do tego piechoty, która weszła we współdziałanie ze spieszonymi dragonami ${ }^{47}$. Mamy więc do czynienia z uzupełnianiem się dwu formacji: dragoni docierali na miejsce szybciej i wiązali walką przeciwnika, piechota, po przybyciu, nasiliła działania, zwiększyła potencjał uderzeniowy dragonów. Dochodzi do kumulowania się wartości bojowej obu formacji.

Wysunięcie się taboru moskiewsko-kozackiego z lasu otworzyło drogę do zmasowanego, dookolnego ataku obu dywizji polskich hetmanów oraz ordy ${ }^{48}$. Atak ten, mimo dużego poświęcenia, nie rozerwał na trwałe taboru, co jeszcze raz pozwala podkreślić roztropność decyzji hetmanów o zaniechaniu szturmu na

\footnotetext{
${ }^{46}$ Ibidem, s. 143.

${ }^{47}$ P. G ord o n, op. cit., vol. II, s. 59; Diaryusz..., s. 151; J. L u b o m i r s k i, op. cit., s. 53;
} S. Le s z c z yń s k i, op. cit., s. 76.

${ }^{48}$ J. L u bo mirs k i, op. cit., s. 54. 
tabor wszystkimi siłami 10 dni wcześniej. Zagrożenie, jakim był tabor w pierwszych dniach starć, widać zwłaszcza wówczas, jeśli uzmysłowimy sobie, że nie dawał się rozerwać teraz, po 10 dniach, na gorszej, bo nieprzygotowanej pozycji. Dodajmy do tego wyobrażenie, jak mocno zmalał ogół tego, co możemy określać potencjałem bojowym sił moskiewsko-kozackich, więc morale, zapasy amunicji, sprzęt uszkadzany w toku walk i polowej eksploatacji, stan i liczba żołnierzy wskutek nieudanych wycieczek, strat od ognia artylerii, szarpania przez jazdę w marszu na Cudnów i wreszcie straty ariergardy po szarży zapoczątkowanej przez Wilczkowskiego. Doprawdy jest to jeden z przypadków, który obok najświetniejszych zwycięstw polskich może bronić staropolskich (czy polskich w ogóle) metod wojowania przed ogólnymi zarzutami o brak racjonalizmu, systematyczności, pokładanie zbytniej wiary w przypadek i poświęceniu żołnierzy. Obok współdziałania i uzupełniania się formacji wojsk Rzeczypospolitej, o wyższości sztuki wojowania Polaków stanowi właśnie ekonomia sił, osiąganie znacznego efektu z czasem bardzo dużym poświęceniem jednostek (np. Wilczkowski i jego chorągiew, później regiment Niemirycza, chorągwie pod Sokolnickim i pod Kaweckim), ale oszczędzaniem ogółu stanu armii.

Kolejne wyraźnie wyodrębnione starcie ${ }^{49}$ zostało rozegrane podczas próby przeprawy taboru Szeremietiewa i Cieciury przez niewielką, ale trudną do pokonania, bagnistą rzeczkę Ibr. Po raz kolejny walki we współdziałaniu miały podobny charakter. W obliczu nadarzającej się okazji, tak jak to było podczas pokonywania lasu rano i wcześniej, 14 września, na Kutyszczu, dowództwo polskie podjęło decyzję o wysłaniu przeciw taborowi tych jednostek, które - wydawać by się mogło - były najmniej predestynowane do szturmów takich pozycji, jak unieruchomiony tabor, więc pozycji warownych i zaopatrzonych w broń strzelecką oraz artyleryjską. Dodajmy, że rzeczka Ibr, stanowiąca bezsprzecznie dotkliwą przeszkodę dla masy spiętych łańcuchami wozów taborowych, nie była też przecież bynajmniej ułatwieniem dla działań jazdy. Mimo to jazda dywizji Lubomirskiego ruszyła nad przeprawę na Ibrze, by utrudnić taborowi jego pokonanie. Zatrzymanie masy wojsk otaborowanych okazało się niemożliwe, ale ich marsz został spowolniony na tyle, by tyły taboru dogoniła piechota i artyleria polska ${ }^{50}$. Tak jak w poprzednich starciach, współdziałanie otworzyła jazda, przygważdżając przeciwnika, krępując jego ruchy lub przynajmniej je kanalizując. Co więcej, nawet taki sukces, jakim było dla wojsk moskiewskich i kozackich utrzymanie się w marszu, mimo przeszkody terenowej i walki z jazdą, okupiony był znacznie gorszymi warunkami do przygotowania się do nadejścia piechoty i artylerii polskiej.

${ }^{49}$ Nie licząc nieustannych szarpanych walk prowadzonych przez jazdę polską i tatarską wobec oddziałów osłaniających z zewnątrz tabor i pojedynczych prób jego rwania.

${ }^{50}$ Memorabilis..., s. $92-95$. 
Tu ujawnił się kolejny walor współdziałania w wykonaniu wojsk polskich. Nietrudno przypuszczać, że wciąż przeważająca pod względem artylerii armia Szeremeta i Cieciury mogłaby, gdyby nie niepokojenie jej przez wysuniętą nad przeprawę jazdę pod komendą Lubomirskiego, się przygotować na nadejście z przewidywalnego kierunku piechoty i artylerii polskiej. Mniej zwrotne i wolniejsze formacje musiałyby wchodzić do akcji pod ogniem dział moskiewskich. Zwłaszcza zajmowanie pozycji przez polską artylerię pod ostrzałem lepszej artylerii moskiewskiej byłoby okupione stratami. Wreszcie, chcąc ratować to, co było możliwe do uratowania, Szeremietiew mógłby, gdyby nie nacisk jazdy, pozostawić na jednej stronie Ibru baterie artylerii z częścią jazdy dla osłony, a resztą sił na trwałe oderwać się od wojsk Rzeczypospolitej, już to marnując ich wysiłki i strategiczny cel rozbicia jego sił albo też przynajmniej zmuszając masy piechoty do ataków na moskiewskie pozycje ${ }^{51}$. W takiej sytuacji artyleria mogła być nawet częściowo porzucona przez Moskwicina, a jego jazda mogłaby w ostatniej chwili z resztą artylerii oderwać się od wroga wycieńczonego szturmami na nabrzeżne baterie i podążyć jako ariergarda taboru. To właśnie odcięcie ariergardy rano, po szarży dwu chorągwi husarskich z posiłkami, a następnie osaczenie i spowalniane awangardy na przeprawie $z$ jednoczesnym, potencjalnym przynajmniej zagrożeniu dla reszty taboru ze strony reszty jazdy spowodowały, że moskiewski wódz nie mógł się oderwać od nadciągającej polskiej artylerii i piechoty. Te formacje otworzyły ogien do nowo wydzielonej ariergardy moskiewskiej. Jak podaje A. Hniłko, na pomoc ariergardzie poszła cała rajtaria Szeremietiewa $^{52}$. Nie była ona $\mathrm{w}$ stanie $\mathrm{w}$ walce manewrowej zapewnić osłony własnej piechoty przed polską jazdą, skierowana zaś przeciw piechocie hetmanów była rażona ogniem współdziałającej z tą piechotą artylerii polskiej. Mamy tu więc po raz pierwszy najbardziej klasyczny z modeli współdziałania, bliski założeniom jeszcze szesnastowiecznym, z czasów Consilium Jana Amora Tarnowskiego. Piechota i artyleria odbijały przeciwnika i raziły z dystansu, jazda krępowała jego działania i uderzała punktowo. Przykład tego współdziałania najlepiej bodaj obrazuje to, na co starałem się zwrócić uwagę w części wstępnej, gdy charakteryzowałem siły Rzeczypospolitej, podkreślając ich harmonijność. Piechota okazała się na tyle silna, że nie wymagała obrony przez własną jazdę przed wszelkimi akcjami nawet licznej jazdy typu niemieckiego w służbie moskiewskiej ${ }^{53}$. Artyleria dzięki właściwemu kierowaniu ogniem prezentowała poziom precyzji, który pozwalał jej osłaniać i wspierać piechotę. Jazda górowała nad przeciwnikiem w polu na tyle, by móc zadawać mu dotkliwe ciosy, choć oczywiście samodzielne rwanie przez nią taboru było w tej sytuacji nadal zbyt ryzykowne. Zaburzyłoby

\footnotetext{
${ }^{51}$ Ibidem, s. 94.

${ }^{52}$ A. H n iłk o, op. cit., s. 55.

${ }^{53}$ Memorabilis..., s. 94.
} 
to zresztą istotę klasycznego modelu współdziałania, jak to było pod Dobryniczami czy w czasie odsieczy Moskwy, gdy związanie walką husarii dało możliwość dość swobodnego ataku mas jazdy moskiewskiej.

Harmonijność struktury wojsk polskich i zastosowanie dwu modeli współdziałania, najpierw z jazdą w roli wiążącej, potem modelu klasycznego „trójpodziału ról" w regularnej bitwie, dały efekt w postaci bardzo korzystnej dla strony polskiej proporcji strat. Źródła różnią się co do liczby poległych podkomendnych Szeremietiewa i Cieciury od kilkuset ${ }^{54}$ do $3000^{55}$. Istotna jest tu jednak proporcja strat obu stron. W każdym ze źródeł wskazuje ona na stosunek 1:10 lub nawet większy. Do tego pewne jest, że ścigające Moskwicinów i Kozaków wojska polskie i tatarskie urwały jakąś część wozów i artylerii. Najmniejsze liczby to 400 wozów przejętych przez stronę polsko-tatarską oraz siedem dziat ${ }^{56}$. Źródła nie potwierdzają, czy działa te zostały użyte bojowo, należy pamiętać o braku standaryzacji artylerii w tych czasach ${ }^{57}$. Nie wiemy też, jaka była realna przydatność środków przejętych w wozach i samych wozów (wojska Rzeczypospolitej cierpiały wszak na chroniczny brak koni pociągowych, więc zdobyte wozy, o ile nie wzięto też zwierząt, mogły pozostać unieruchomione). Pewne jest to, że jakimkolwiek zyskiem dla Polaków i Tatarów była zdobycz, to z pewnością większym problemem była dla izolowanych i ściganych wojsk moskiewskich i kozackich strata tego, co pozostało nad Ibrem (lub pogrążyło się w jego nurcie).

Wyjąatkowym sukcesem taktycznym strony polskiej musi być utrata dziesięciokrotnie mniejszej liczby ludzi w walce ze zdyscyplinowanym, zdeterminowanym, licznym, dobrze uzbrojonym i dowodzonym oraz doświadczonym przeciwnikiem, w dodatku kryjącym się za „umocnieniami”, jakie stanowiła ruchoma twierdza - tabor, przeciwnikiem przeważającym artylerią i cierpiącym tylko takie utrudnienia terenowe, jak te, które krępowały też polskie atuty taktyczne (podmokły teren, las). Tak jak dla taboru przeszkodą były las i rzeczka, tak też dzieliły one siły polskie i powinny ograniczać przydatność jazdy polskiej, w mniejszym stopniu też tatarskiej. Piechota i artyleria nie doznawały w tym terenie aż tak dużych ograniczeń, ale za ograniczenie dla strony polskiej powinny tu być uważane: ich niewielka przydatność piechoty i artylerii w pościgu oraz przewaga w tych rodzajach wojsk należąca do strony moskiewskiej (działa jakościowo i ilościowo, piechota ilościowo) oraz kozackiej (piechota ilościowo).

${ }^{54}$ P. G o r d o n, op. cit., vol. II, s. 60.

${ }^{55}$ Journal...; J. L u b o m i r s k i, op. cit., s. 54. Cf. wcześniejsze szacunki wg Journal i Gordona dotyczące relacji strat $\mathrm{z}$ walk pod Lubarem.

${ }^{56}$ Obszerne zestawienia i porównania liczb podaje A. H n iłk o, op. cit., s. 55. Rozbieżności między przekazami są jednak zbyt duże, by istniała możliwość wskazania najbardziej prawdopodobnej liczby. $C f$. wcześniejsze szacunki wg Journal i Gordona dotyczące relacji strat z walk pod Lubarem.

${ }^{57}$ Przynajmniej zaś standaryzacji powszechnej, w rozumieniu wieku XX i XXI. 


\section{Wnioski}

Konkluzje uzyskane w wyniku analizy pierwszej części kampanii cudnowskiej z punktu widzenia współdziałania to cztery powiązane wzajemnie stwierdzenia.

Po pierwsze, struktura armii polskiej, uzupełniona dużym zgrupowaniem tatarskim, była podatna na współdziałanie, modułowa. Formacje uzupełniały się nawzajem. Ich zróżnicowanie oraz elastyczność były o wiele większe niż w armii przeciwnika. Dawało to możliwość kreowania współdziałania w kilku różnych wariantach: czy to ad hoc, przez dowódców, czy też tworzenia się współdziałania oddziałów spontanicznie, w wyniku reakcji walczących grup na zaistniałe punktowo sytuacje.

Po drugie, współdziałanie sił polskich wystąpiło na każdym etapie walk. Stronie polskiej dało to wyraźne atuty w konfrontacji z przeciwnikiem. Wojska polskie dominowały pod względem inicjatywy, narzucały ją stronie moskiewsko-kozackiej, redukowały ją do roli podmiotu biernego, unikającego walki, próbującego zerwać kontakt bojowy, szukającego ucieczki lub wsparcia. Sytuację taką udało się stworzyć i utrzymać mimo konfrontacji z silnym i dobrze dowodzonym przeciwnikiem.

Po trzecie, współdziałanie nie przebiegało bez zakłóceń. Najpoważniejsze wiązały się z udziałem elementu zewnętrznego dla wojskowości polskiej, czyli Tatarów. Niedoskonałości współdziałania widać zwłaszcza w dwu momentach: na początku pierwszego starcia, pod Kutyszczem, oraz podczas pierwszej próby szturmu (tu jednak niesubordynacja, spowodowana nadmiarem inicjatywy oddolnej, cechowała także niektóre regimenty niemieckie i jednostki autoramentu narodowego). Wątpliwości budzi postawa Tatarów w ostatnim z etapów pierwszej części kampanii, czyli podczas walk $\mathrm{z}$ taborem w marszu na Cudnów ${ }^{58}$. Można zatem wskazywać niedoskonałości współdziałania, jednak głównie w warunkach traktowania go jako abstrakcyjnego ideału. Właściwe naukom humanistycznym będzie raczej powiązanie współdziałania z czynnikiem indywidualnym, zbiorowym, społecznym, narodowym. Wobec powyższego należy wysoko ocenić współdziałanie ogółu wojsk polskich, tj. obydwu dywizji hetmańskich. Niedoskonałość skorelowania działań z odmiennym etnicznie i taktycznie elementem tatarskim można odnieść do wniosków zaprezentowanych poniżej.

Po czwarte, współdziałanie w pierwszej części kampanii cudnowskiej można określić uogólniająco jako działania realizowane często ad hoc. Obok metodycznie wdrażanych schematów współdziałania możemy obserwować bardzo częste, spontaniczne odruchy angażowania się w walkę. Widać je i w działaniach jazdy dywizji polskich (pierwszy szturm na tabor warowny pod Lubarem, szarża na

${ }^{58}$ Memorabilis..., s. 92. 
ariergardę), i w postawie piechoty (zwłaszcza oddział gen. Grothausa, uparcie kontynuujący walki w pierwszym walnym starciu). Cechy improwizacji ma natomiast współdziałanie $\mathrm{z}$ Tatarami. Jest to wynik ich dużej samodzielności w zakresie dowodzenia i utrudnionej komunikacji.

\section{BOGUSZ BOMANOWSKI}

\section{Cooperation of Polish armed forcesduring first part of hostilities of Cudnovian campaign}

This researchers are intended to comprehend and put under analyses a set of modes of cooperation performed by different military units under Polish command during first part of the cudnovian campaign, including hostilities under Kutyszcze, Lubar and during the retreat of Moscovian-Cossack army on the path to Cudnow.

A proper campaign became my choice as a subject of researches, because indigenous and unique Polish-Lithuanian art of War achieved very high level of development in this period, perfected by great hetmans since the end of $16^{\text {th }}$ century. It gives a good background to examine methods of cooperation by different types of forces in the army of Polish-Lithuanian Commonwealth.

Conclusions made in the wake of analyses devoted to the first part of this campaign could be formed in to four sets.

1. Modular and diverse structure of Polish army amended by large group of Crimean light cavalry is a flexible and versatile power. It gives a large superiority over Moscovian-Cossack forces. Commanders on different levels of command are able to create ad hoc joint task force and to variegate cooperation modes between them.

2. Cooperation is predominant quality of Polish forces during vast majority of sufficient actions in this campaign. Diacritically large spectrum of available types of specialized units causes a mixture of capabilities and complicated scenarios of cooperation, which is used with great outcome to step up the effectiveness of Polish army. Despite confrontation with very strong discipline of Moscovian-Cossack forces, their sustainable, enduring defense, desperate brave in close combat and good command, there are only one dominant and pervasive force - Polish army and Tatars were creative enough, to bring their opponents to the passive role.

3. Some weak moments in polish-tatar cooperation could be also observed. Especially Tatars are the reason of some havoc in collective actions. They attack without permission (battle of Kutyszcze) or withhold their units to avoid losses, making Poles to fight alone (by the Ibr river).

4. Ad hoc although not hasty actions are performed alongside with disciplined methodical operations. Commanders of small units (under regimental level: banners, squadrons etc.) are creative but also it is visible, that among all polish forces officers are provided with a dependable background of unified procedures which they choose to operate in a wide spectrum of tactical situations. Hostilities started by the charge of hussars under Wilczkowski and continued by action of musketeers is a god example here. It is a modern army with standardized roles and procedures, but not bounded with it. Enthusiasm of soldiers and their readiness to support each other is showed by units, who spontaneously engage the cooperation. 